Rok XV (2020) | 1 (29)| S. 267-281

https://doi.org/10.12797/LV.15.2020.29.17

Ewa Horyń ๑

Uniwersytet Pedagogiczny im. KEN, Kraków

ewa.horyn@up.krakow.pl

Marceli Olma (1)

Uniwersytet Pedagogiczny im. KEN, Kraków

marceli.olma@up.krakow.pl
Mirosław Michalik •

Uniwersytet Pedagogiczny im. KEN, Kraków

miroslaw.michalik@up.krakow.pl

\title{
U ŹRÓDEŁ POLSKIEJ TERMINOLOGII LOGOPEDYCZNEJ. W KIERUNKU BADAŃ ANAGNOSTYCZNYCH ${ }^{1}$
}

\author{
Profesorowi Janowi Ożḋyńskiemu - \\ inicjatorowi badań nad polską terminologia logopedyczna
}

Słowa klucze: lingwistyka stosowana, terminologia logopedyczna, leksyka profesjonalna, słownictwo medyczne

Keywords: applied linguistics, logopedic terminology, professional vocabulary, medical vocabulary

\section{Wprowadzenie}

Polska logopedia pretenduje do miana dyscypliny naukowej od początku lat 60 . XX w. (por. Kaczmarek 1991: 5)². Już wtedy termin logopedia miał dwa znaczenia.

1 Wkład poszczególnych autorów w powstanie artykułu jest równy i wynosi po 33,3\%. Koncepcja oraz wykonanie są w pełni współautorskie.

2 Początków polskiej stricte naukowej refleksji logopedycznej należy szukać w Lublinie. W $1960 \mathrm{r}$. zostało w tym mieście powołane do istnienia czasopismo „Logopedia. Zagadnienia kultury żywego słowa" - do tej pory najbardziej prestiżowy polski periodyk dotyczący zaburzeń mowy. W roku 
Pierwsze wskazywało na działalność praktyczną, wdrażanie procedur i strategii postępowania logopedycznego w zakresie działań terapeutycznych (Kaczmarek 1991: 5-6; Grabias 2012: 59-6o; Michalik 2013: 14). Drugie podkreślało naukowy, teoretyczny, autonomiczny, choć heterogenny jej status (Grabias 1991: 27; Kaczmarek 1991: 6; Michalik 2013: 14) ${ }^{3}$. Co może zaskakiwać, w okresie refleksji przednaukowej, tj. na początku XX w., przedmiotem logopedii trafnie uczyniono zaburzenia mowy i ich usuwanie, zaś u zarania logopedii jako nauki za jej przedmiot Leon Kaczmarek uznał mowę, czyli - jak uważał - akt w procesie porozumiewanie się językowego (Kaczmarek 1991: 6). Z dzisiejszej perspektywy wiadomo, że koncepcja Kaczmarkowska okazała się zbyt szeroka, ustępując pola reaktywowanemu przez Stanisława Grabiasa sądowi na temat logopedii, której przedmiotem są zaburzenia mowy, a ściślej zakłócenia w funkcjonowaniu reguł komunikacji językowej, ich usuwanie i niedopuszczanie do nich (Grabias 1991: 45).

Logopedia Kaczmarkowska wyodrębniła się z komponentów wiedzy językoznawczej, medycznej, psychologicznej i pedagogicznej (Kaczmarek 1991), zaś wczesna refleksja Grabiasa na temat logopedii podkreślała ścisłe korelacje między nią a naukami medycznymi. Patrząc wstecz, w 2019 r. Grabias napisał:

Nauki medyczne, szczególnie foniatria, utożsamiają logopedię z treścią formuły „zaburzenia mowy i ich usuwanie”. Takie rozumienie logopedii wynika z tradycji badań rozwijających się przez wieki, bo nauki te i tylko one przez długi czas wyznaczały zakres refleksji nad zaburzeniami mowy i jej głębokość (Grabias 2019: 282; por. także Kuczkowski, Cieszyńska 2017: 63-82).

Jeszcze ciaśniej nauki medyczne powiązano z logopedią, gdy już w XX w. powszechnie przyjęto, iż logopedia jest nauką o biologicznych uwarunkowaniach języka i zachowań językowych (Grabias 2012: 57, 2019: 285-287). O roli uwarunkowań endogennych w procesach językowych Grabias (2012: 59) pisał następująco:

Logopedia, nauka o biologicznych uwarunkowaniach języka i zachowań językowych, musi uznać konstatację, że zarówno kompetencja, jak i realizacja wynikają przede

1963 z kolei ukonstytuował się tam Zarząd Główny Polskiego Towarzystwa Logopedycznego, a siedem lat później na Uniwersytecie Marii Curie-Skłodowskiej utworzono pierwszą w Polsce jednostkę naukową badającą zaburzenia komunikacji językowej - Zakład Logopedii UMCS, kierowany wówczas przez prof. Leona Kaczmarka (Kaczmarek 1991: 5; Grabias 2012: 56).

3 Przykładowo Franciszek Grucza, definiując termin nauka z perspektywy nauki o nauce (naukoznawstwa), podaje: „Nauka i praktyka różnią się aspektami teleologicznymi w tym sensie, że pracy naukowej przyświecają cele poznawcze, natomiast pracy praktycznej inne cele. Oba te rodzaje pracy ludzkiej trzeba zatem rozdzielić. Pojęciowe rozdzielenie obu tych zakresów nie oznacza jednak negacji zachodzących między nimi powiązań, a przeciwnie - umożliwia lepsze ich naświetlenie. Okazuje się, że powiązania te są wielorakie. Można je rozważać bądź z punktu widzenia nauki, bądź też z punktu widzenia praktyki. Oba zakresy wzajemnie się warunkują i to na zasadzie jak gdyby odwróconego paralelizmu albo lustrzanego odbicia" (Grucza 1983: 47; por. także Michalik 2013: 14). 
wszystkim z biologicznych możliwości jednostki i są wyrazem mobilności jej mózgu oraz stanu procesów obwodowych uczestniczących w realizacji wypowiedzi.

„Mobilność mózgu” wynika z prawidłowego funkcjonowania ośrodkowego układu nerwowego, zaś za „stan procesów obwodowych” odpowiada część aferentna i eferentna układu nerwowego (Obrębowski 2014: 23) ${ }^{4}$. Dzięki takiej orientacji poznawczej w centrum zainteresowań logopedii jako nauki o biologicznych uwarunkowaniach mowy znalazły się kwestie biologiczno-medyczne dotyczące anatomii, fizjologii i patologii układu nerwowego, aparatu mowy i zmysłów człowieka.

\section{Logopedia jako nauka}

Wyjąwszy urzędników Ministerstwa Nauki i Szkolnictwa Wyższego ${ }^{5}$, praktycznie nikt dziś nie kwestionuje statusu logopedii jako samodzielnej dyscypliny naukowej. „Polska logopedia ostatnich lat - jak dobitnie podkreśla S. Grabias - może się poszczycić takimi osiągnięciami, które rozległością refleksji naukowej i jej poziomem sytuują ją w gronie samodzielnie istniejących nauk o człowieku" (2019: 281). Odwołując się do teorii nauki, głównie w interpretacji neopozytywistycznej, ale wzbogacanej sądami Kazimierza Ajdukiewicza (1960), Karla Poppera (1992), Romana Ingardena (1966), Stanisława Kamińskiego (1992), Stanisława Grabiasa (2019), Franciszka Gruczy (1983), Józefa Życińskiego (1983), Ireneusza Bobrowskiego (1993), przyjmujemy, iż logopedia jako naukowa dyscyplina samodzielna, autonomiczna, transdyscyplinarna, stosowana posiada:

1. swój przedmiot badań - biologiczne uwarunkowania języka i zachowań językowych (Grabias 2019: 285-287);

2. odpowiedni poziom refleksji metanaukowej - posługuje się nie tylko zdaniami o zdaniach o rzeczywistości (nauka), ale również zdaniami o zdaniach o zdaniach o rzeczywistości (metanauka) (Życiński 1983: 82; Bobrowski 1993: 16; Michalik 2018: 8-9);

3. hierarchiczny układ celów diagnostycznych, prognostycznych i anagnostycznych (Logopedia);

4. procedury i narzędzia postępowania badawczego (Metodologia).

Logopedia jako nauka prowadzi trzy rodzaje badań naukowych:

1. podstawowe, czyli wzbogacające i porządkujące wiedzę teoretyczną;

2. stosowane, służące rozwijaniu wyników badań podstawowych w celach praktycznych;

4 Zwyczajowo ze stanem procesów obwodowych łączy się pracę nerwów unerwiających aparat mowy, narządów mowy (aparatu orofacjalnego), głosu i słuchu (por. Kozołub 2003: 127).

5 Por. Rozporządzenie Ministra Nauki i Szkolnictwa Wyższego z dnia 20 września 2018 r. w sprawie dziedzin nauki i dyscyplin naukowych oraz dyscyplin artystycznych, Dz.U. 2018, poz. 1818. 
3. wdrożeniowe, budujące techniki realizowania zamierzonych celów praktycznych (por. Grabias 2019: 291-292).

Z punktu widzenia wybijania się logopedii na naukową niezależność najważniejsze są badania podstawowe.

Jeśli z kolei przyjąć za F. Gruczą (1983: 19), iż na pojęcie nauki sensu largo składa się: podmiot nauki, nauka sensu stricto, której składowe to praca naukowa i jej wytwory, oraz przedmiot nauki - to należy uznać, że i te atrybuty logopedia posiada. Podmiotami logopedii jako nauki są osoby zajmujące się naukowo, ale i zawodowo tą dyscypliną. Logopedia jako nauka sensu stricto jest wynikiem pracy naukowej (służącej głównie celom poznawczym i transferencyjnym $)^{6}$ oraz posiada swoją metodologię, zaś jej przedmiotem są wymienione już powyżej biologiczne uwarunkowania języka i zachowań językowych (ibid.: 19; por. także Michalik 2015: 33-34).

Najważniejszym atrybutem logopedii jako nauki jest jej ciągle tworząca się metodologia, czyli metanauka o metodach badań naukowych, mająca wymiar zarówno konstrukcyjny, służący wypracowaniu nowych rozwiązań, jak i krytyczny, którego celem jest krytyka metod badawczych na jej gruncie stosowanych (por. Puzio, Ziółkowska 1998). Metodologia logopedii jako wytwór pracy naukowej (Grucza 1983: 19) opisuje sposoby przeprowadzania logopedycznych analiz naukowych oraz ocenia jej wartość poznawczą (por. Nowy leksykon). Stara się również odzwierciedlać sposób myślenia badaczy o podejmowanych zadaniach badawczych; obejmuje zatem zarówno uogólnione doświadczenie zbiorowe naukowców - włączając w to i tradycję, i współczesność - jak i indywidualne, innowacyjne poszukiwania poszczególnych jednostek, podejmujących trud rozwiązywania problemów badawczych (Hamerlińska 2017). Porównując natomiast przedmiot metodologii z zagadnieniami teorii nauki, warto zauważyć, iż każda metodologia (w tym metodologia logopedii) zajmuje się przede wszystkim procesem budowania nauki (posiadać musi wymiar dynamiczny i czynnościowy), a dopiero sekundarnie rezultatami tego procesu. Inaczej to teoria metod uprawiania nauki, która opisuje i wyjaśnia stosowane metody oraz prakseologicznie wartościuje uzasadniane i projektowane sposoby uprawiania nauki (Hajduk 2012).

Reasumując: metodologia logopedii, należąc do porządku metanauki, dąży do pełnienia następujących funkcji: krytycznej, konstrukcyjnej (por. Puzio, Ziółkowska 1998), poznawczej, gnoseologicznej (Grucza 1983; Michalik 2015, 2018), prakseolo-

6 Namacalnymi wytworami naukowej pracy logopedycznej są publikacje awansowe (dysertacje doktorskie oraz monografie habilitacyjne) rzeczonych podmiotów logopedii uzyskane w ostatnich latach. Mimo iż formalnie stopnie naukowe są uzyskiwane najczęściej w dyscyplinie językoznawstwo, kilkanaście stopni doktora habilitowanego oraz kilkadziesiąt doktora - licząc szacunkowo - posiada specjalność logopedyczną. Informacje te podajemy, uwzględniając efekty kształcenia kadry naukowej najważniejszych ośrodków badań logopedycznych, tj. lubelskiego (UMCS), gdańskiego (UG), katowickiego (UŚ), warszawskiego (UW oraz APS), łódzkiego (UŁ) oraz krakowskiego (UP). 
gicznej (Hajduk 2012) oraz weryfikującej (Hamerlińska 2017). By je pełnić, musi posiadać wymiar dynamiczny i czynnościowy (Hajduk 2012; por. także Michalik 2018).

Obok metodologii innym wyznacznikiem naukowości jakiejś sfery ludzkiej aktywności jest jej terminologia, służąca porządkowaniu dziedzin i dyscyplin wiedzy, zaprowadzająca poznawczy ład, głównie poprzez z jednej strony upowszechnianie terminów wspierających procesy poznawcze, $\mathrm{z}$ drugiej - usuwanie zbędnej pojęciowej różnorodności (Gajda 1990: 114).

W przypadku wybijającej się na autonomię logopedii jako nauki rozważania o terminologii dyscypliny były naturalnym uzupełnieniem refleksji nad jej przedmiotem (zakresem pojęciowym) oraz metanaukowej samoświadomości podmiotów nią się zajmujących (Ożdżyński 1994a: 7). Z pewnej perspektywy czasowej, ale i współczesnego poziomu refleksji logopedycznej, można wyodrębnić dwa okresy refleksji na temat terminologii logopedycznej:

1. Kaczmarkowski, wczesny, przypadający na lata 1960-19937, w którym terminologia logopedyczna, traktowana zresztą dość instrumentalnie, miała wspierać dążenia do emancypacji logopedii jako samodzielnej dyscypliny naukowej, stanowiącej składową bloku humanistyczno-biologicznego (Kaczmarek 1991: 5). Ówczesne rozważania teorioznawcze dotyczyły przede wszystkim samego terminu logopedia, nazw działów i specjalizacji logopedii, korelacji między terminem mowa a przedmiotem logopedii, ale również nazw jednostek patologii mowy. Cezura graniczna tego okresu przypada na rok 1993, w którym to ukazały się dwa słowniki logopedyczne autorstwa Józefa Surowańca: Podręczny słownik logopedyczny oraz Słownik słów kluczowych w logopedii ${ }^{8}$. Pierwszy uwzględniał szereg terminów z kartoteki L. Kaczmarka i był podporządkowany koncepcji metodologicznej lubelskiej szkoły logopedycznej (Ożdżyński 1994a: 9).

2. Dojrzały (1994-2015). Początek lat 9o. XX w. to czas ważnych zmian na mapie polskiej logopedii. Już w 1984 r. na Uniwersytecie Gdańskim tworzy się Zakład Logopedii. W 1992 r. zostaje utworzona Komisja Rozwoju i Zaburzeń Mowy PAN, a w 1993 r. zostaje powołany do istnienia Zakład Logopedii i Lingwistyki Edukacyjnej w ówczesnej krakowskiej Wyższej Szkole Pedagogicznej. Polska logopedia z lubelskiej staje się ogólnopolska, naukowo zdywersyfikowana, różnorodna. Będzie to miało wpływ m.in. na analizy terminologiczne i badania terminoznawcze oraz sposoby ich implementacji. Jeśli chodzi o samą refleksję naukową na temat terminologii logopedycznej, wyznaczają ją dwie wyraźne i fundamentalne dla

7 W 1960 r., jak już wspomniano, ukazał się pierwszy numer czasopisma „Logopedia. Kultura żywego słowa”. To umowna, choć powszechnie przyjęta data ukonstytuowania się logopedii jako nauki.

8 Rok wcześniej ukazał się drukiem pierwszy z jego ważnych słowników: Słownik terminów logopedycznych (Surowaniec 1992). Warto dodać, iż w 1999 r. wydano w Krakowie ostatni z ważnych słowników logopedycznych Józefa Surowańca, Logopedyczny słownik terminologii diagnostycznej (1999). 
całej polskiej logopedii cezury. Pierwsza wiąże się z konferencją naukową (1992) i tomem pokonferencyjnym zatytułowanymi Polska terminologia logopedyczna (Ożdżyński 1994b). Wydarzenia te, zorganizowane przez Jana Ożdżyńskiego w krakowskiej WSP, a objęte patronatem naukowym przez Komisję Rozwoju i Zaburzeń Mowy PAN, de facto zainicjowały systemowe i wieloaspektowe badania polskiej terminologii logopedycznej. Cezura końcowa przypada na rok wydania Standardów postępowania logopedycznego, zredagowanych przez profesorów Stanisława Grabiasa, Jolantę Panasiuk, Tomasza Woźniaka w 2015 r. Ten najważniejszy polski akademicki podręcznik logopedyczny, precyzując standardy postępowania diagnostycznego i terapeutycznego praktycznie wszystkich zaburzeń mowy, kodyfikuje i doprecyzowuje terminologię wiążącą się z wymienionymi procedurami (diagnozą i terapią zaburzeń komunikacji językowej).

Należy żywić nadzieję, iż wystandaryzowane ustalenia terminologiczne zawarte $\mathrm{w}$ fundamentalnej pracy z $2015 \mathrm{r}$. zyskają powszechną akceptację wszystkich środowisk i ośrodków naukowych odpowiedzialnych za kształcenie logopedów. W przeciwnym wypadku dezynwoltura terminologiczna, jaka ciągle panuje w polskiej logopedii, będzie miała trudny do wyobrażenia, negatywny wpływ na proces terapii zaburzeń mowy. Niestety, ciągle wiele jednostek patologii mowy jest określanych niejednoznacznie, za pomocą terminów o różnych zakresach semantycznych, a nawet treściach. W konsekwencji do źle, nieprecyzyjnie wyznaczonej logopedycznej jednostki nozologicznej są wybierane nieadekwatne procedury i strategie postępowania logopedycznego, które przyczyniają się do nieefektywności działań terapeutycznych, godząc tym samym w najważniejszą, również dla logopedii, zasadę: Primum non nocere. Powszechna akceptacja ujednoliconej terminologii dotyczącej zaburzeń mowy, na wzór obligatoryjnie przyjętej przez środowisko medyczne klasyfikacji chorób (ASA), do logopedii jako dyscypliny naukowej wprowadziłaby - parafrazując S. Gajdę (1990: 114) - terminologiczny ład.

\section{Projekt badawczy}

Fiasko dotychczasowych działań służących ujednoliceniu terminologii logopedycznej to główna motywacja do podjęcia badań w ramach projektu Diachroniczne aspekty polskiej terminologii logopedycznej ${ }^{9}$. Porządkowanie terminologii ściśle wiąże się z zebraniem oraz systematyzacją leksyki profesjonalnej odnoszącej się do diagnozy i terapii zaburzeń mowy, co wiązać się musi z sięgnięciem do początków

9 W projekcie badawczym noszącym tytuł „Diachroniczne aspekty polskiej terminologii logopedycznej” biorą udział pracownicy Katedry Języka Polskiego IFP Uniwersytetu Pedagogicznego im. KEN w Krakowie: dr hab. prof. UP Ewa Horyń, dr hab. prof. UP Marceli Olma, dr hab. prof. UP Mirosław Michalik. 
logopedii jako jednego z nurtów lingwistyki stosowanej sytuującej się głównie w sąsiedztwie nauk medycznych, ale też nierzadko sięgającej do doświadczeń pedagogiki i psychologii. Diachroniczna orientacja eksploracji słownictwa medycznego, przeprowadzana zespołowo w ramach badań anagnostycznych (Logopedia), wynika z przeświadczenia, iż:

1. „metodologiczny trud zgłębienia jakiegoś problemu badawczego obejmować musi - jak podkreśla Agnieszka Hamerlińska - zarówno uogólnione doświadczenie zbiorowe naukowców, włączając w to i tradycję (podkr. - E.H., M.M., M.O.), i współczesność - jak i indywidualne, innowacyjne poszukiwania poszczególnych jednostek" (Hamerlińska 2017: 90-91);

2. „konkretne zalecenia poprawnościowe muszą opierać się na zbadaniu specyfiki rozwoju (podkr. - E.H., M.M., M.O.) konkretnej terminologii” (Ożdżyński 1994a: 7);

3. logopedia jest nauką o biologicznych uwarunkowaniach języka i zachowań językowych (Grabias 2019: 285-287), a do biologii człowieka, również w ujęciu aplikacyjnym, najbliżej jest dziedzinie nauk medycznych.

Prezentowana inicjatywa badawcza zakłada na początek eksplorację materiału językowego opartą na ekscerpcji zgromadzonych źródeł. Jej punktem wyjścia będą słowniki ogólne i specjalistyczne oraz czasopisma medyczne zawierające terminologię logopedyczną, a także materiały rękopiśmienne z zakresu historii medycyny. Omówienie zebranego materiału polegać ma na wskazaniu genezy (w tym etymologii) i rozpoznaniu struktury zebranych terminów medycznych, scharakteryzowaniu składu nazw jedno- i wieloczłonowych oraz ich proweniencji, ustaleniu wpływów języków obcych (pożyczek leksykalnych i semantycznych, głównie, choć nie tylko, z łaciny i greki), omówieniu budowy słowotwórczej nazw rodzimych i mechanizmów towarzyszących procesom neosemantyzacji ${ }^{10}$.

Niezależnie od dotychczasowych ustaleń dokonanych przez badaczy językoznawców (zazwyczaj jednak nielogopedów) projektowanym zamiarom przyświecać będzie przede wszystkim perspektywa logopedyczna ${ }^{11}$.

10 W kolejnych publikacjach naukowych zostaną zaprezentowane: metoda opisu wybranego terminu logopedycznego, charakterystyka zgromadzonych źródeł wykorzystanych do analizy zebranego materiału badawczego, a także określenie ram czasowych eksplorowanego materiału.

11 Połączenie językoznawczego i logopedycznego punktu widzenia w podjętych badaniach wynika ściśle z postulatu, by każdy system terminologiczny był oceniany z punktu widzenia: a) treści, tj. odbicia w nim poziomu wiedzy danej dyscypliny; b) budowy logicznej systemu i/lub zasad organizacji zbioru; c) kształtu językowego składników (Ożdżyński 1994a: 7). 


\section{Stan badań nad słownictwem medycznym oraz anatomicznym}

W początkach doby średniopolskiej problematyka zdrowotna oraz literatura medyczna zdecydowanie ustępowały pod względem ilościowym i jakościowym piśmiennictwu o tematyce religijnej, parenetycznej czy polemicznej. Pierwocin terminologii lekarskiej niejednokrotnie poszukiwać należy w ówczesnych słownikach farmaceutycznych ${ }^{12}$ czy w herbarzach informujących o leczniczym działaniu ziół ${ }^{13}$. Autorzy tych leksykonów, które miały charakter poradników, byli nierzadko jednocześnie botanikami, aptekarzami i lekarzami, dysponującymi gruntownym wykształceniem zdobytym w ośrodkach uniwersyteckich poza granicami kraju, a jednocześnie doskonałą znajomością rodzimej flory. Oprócz nazw leków i ich komponentów oraz wskazówek co do dawkowania medykamentów naturalnego pochodzenia szesnastowieczne kompendia notują nazwy chorób i niedomagań, a także nazwy anatomiczne.

$\mathrm{W}$ dobie renesansu autonomiczną pozycję $\mathrm{w}$ omawianym zakresie zajmuje dzieło Wojciecha Oczki zatytułowane Przymiot (Kraków 1581), które jest pierwszym na gruncie polskim całościowym, uszczegółowionym ujęciem wiedzy dawnych Polaków o jednej tylko chorobie (kile). Z uwagi na nowatorskie podejście autora oraz jego kreatywność w zakresie specjalistycznej leksyki uznaje się go za jednego z twórców polskiej medycyny, a w jej obrębie polskiej terminologii medycznej.

Począwszy od XVI w., polskie słownictwo lekarskie jest utrwalane w słownikach, zielnikach (herbarzach) oraz poradnikach medycznych (Masłowski 1977: 10), wzbogacanych wyrazami pochodzącymi z języka potocznego, żargonów środowiskowych, wreszcie języków obcych: greki oraz łaciny (ibid.: 10). Spośród źródeł leksykograficznych, w których odnaleźć można słownictwo medyczne, do najbardziej poczytnych należą słowniki języka polskiego ${ }^{14}$, np. Jana Mączyńskiego (1564), Grzegorza Knapskiego (1621), Michała Abrahama Trotza (1764) czy Samuela Bogumiła Lindego (1807-1814). Wśród zielników warto wymienić dzieła: Stefana Falimirza (1534), Hieronima Spiczyńskiego (1542), Marcina Siennika (1568) czy Szymona Syreniusza $(1613)^{15}$. W tym też okresie znaczny wpływ na rozwój terminologii lekarskiej mają uczeni i lekarze związani z Akademią Krakowską, a później również z Akademią Zamojską. W ówczesnym środowisku uniwersyteckim powstały prace Macieja z Miechowa, Szymona z Łowicza, Marcina z Urzędowa czy Józefa Strusia (Okoniowa 2018: 145).

12 Np. Onomasticum trilingue, Latino-Germano-Polonicum rerum et verborum ad officinam pharmaceuticam spectantium... Pawła Guldeniusza.

13 Zamieszczone w nich nazwy roślin leczniczych były wielokrotnie analizowane z punktu widzenia lingwistyki w pracach Ludwiki Wajdy-Adamczykowej (zob. 1989), a zwłaszcza Anny Spólnik (zob. 1988, 1990). Wykaz źródeł leksykograficznych przytaczamy za: Jankowiak 2011a: 98. 
W kolejnych dwóch stuleciach pojawiają się równie ciekawe opracowania terminologii medycznej. Warto w tym miejscu wspomnieć m.in. o Janie Ursinusie, Christianie Heinrichu Kirchheimie czy Jędrzeju Krupińskim (Masłowski 1977: 11).

W wieku XIX następuje poszerzenie zasobu leksykalnego o słownictwo specjalistyczne. Jak podaje Lucyna A. Jankowiak (2011a: 97), zjawisko to „wiązało się zapewne $\mathrm{z}$ intensywnym rozwojem nauk i $\mathrm{w}$ związku $\mathrm{z}$ tym $\mathrm{z}$ koniecznością nazywania nowych desygnatów [...], z porządkowaniem i ujednolicaniem już istniejącej polskiej terminologii medycznej”. W tym stuleciu znaczny wpływ na rozwój piśmiennictwa medycznego miały prace polskich lekarzy. Należy wspomnieć tu o Fryderyku Skoblu oraz Józefie Majerze, którzy opublikowali Słownik anatomiczno-fizjologiczny (1838) (Jankowiak 2011a: 98). W 1868 r. Skobel i Aleksander Kremer wydali Słownik łacińsko-polski wyrazów lekarskich, w 1880 r. ukazał się Słowniczek wyrazów psychiatrycznych Stanisława Janikowskiego, rok później powstał Słownik terminologii lekarskiej polskiej (ibid.: 99), opracowany przez m.in. Józefa Oettingera i A. Kremera, a w 1905 r. ukazała się jego poszerzona, unowocześniona wersja (ibid.: 100).

Okres międzywojenny przynosi wydanie Stownika lekarskiego polskiego do dziatu chorób skórnych $i$ wenerycznych (1921), dwutomowego Polskiego słownika lekarskiego (1931-1933) Dowmonta Franciszka Giedroycia, a także Polskiego słownika lekarskiego radiologicznego i światłoleczniczego (1933) pod redakcją Zygmunta Grudzińskiego i Zygmunta Stankiewicza (Jankowiak 2011a: 100).

Jak podaje Jan Masłowski, w latach powojennych wysiłek wydawniczy kierowany był przede wszystkim na słowniki dwujęzyczne. Oprócz zagadnień leksykalnych główny nacisk kładziono na poprawność języka w medycynie (Masłowski 1977: 15). W 1981 r. został wydany Polski słownik medyczny, ,jego poprawiona i wznowiona wersja ukazała się w 1996 r. jako Wielki słownik medyczny" (Jankowiak 2011a: 101).

Jeśli chodzi o prace koncentrujące się na opisie terminologii medycznej, dotychczas z tego zakresu ukazało się kilka pozycji. Jeszcze w połowie XIX w. Józef Majer, lekarz leksykograf, uznawany za „ojca duchowego” polskiego słownictwa lekarskiego, opublikował rozprawę, w której poświęcił wiele uwagi terminom specjalistycznym (Ross 1965: 228). Ponad sto lat później terminologia lekarska do XIX w. została opracowana przez Felicję Wysocką (1980, 1994, 1995, 1999, 2007, 2013), słownictwo lekarskie drugiej połowy XIX i przełomu XIX i XX w. opisała L.A. Jankowiak (np. 2011a, 2011b).

Nazewnictwu chorób zarejestrowanych w opracowaniach medycznych z lat 60 . i 7o. XX w. poświęcona została odrębna monografia autorstwa Karin Musiołek-Choiński (1986), w której analizie poddano grupę ponad 4 tys. nazw z różnych dziedzin medycyny: ,anatomii patologicznej, chirurgii, dermatologii, epidemiologii, ginekologii, neurologii, okulistyki, ortopedii, otolaryngologii, pediatrii, psychiatrii, radiologii i wenerologii” (ibid.: 9-10). Autorka skupiła się na analizie formalnogramatycznej zgromadzonej terminologii, a także na opisie tendencji w zakresie funkcjonowania nazw chorób. 
Na gruncie polskim powstały również liczne opracowania językoznawcze, głównie o charakterze przyczynkarskim. Zawierają one opis słownictwa medycznego w różnych typach tekstów: słownikach lekarskich, księgach metrykalnych, poradnikach zdrowia lub materiałach dydaktycznych itp. Należą tu prace m.in.: Elżbiety Kędelskiej (1978), Elżbiety Umińskiej-Tytoń (1989, 1990), Teresy Friedelówny (1991, 1992, 1994), Haliny Wiśniewskiej (1991), Jolanty Migdał (2002), Jerzego Janiuka (2005), Barbary Pukalskiej (2013), Magdaleny Ławnickiej-Borońskiej i Kamili Kubackiej (2016), Doroty Gonigroszek (2017) czy Adama Dombrowskiego (2018). Do grupy tej zaliczyć można również publikacje Jana Doroszewskiego (1999, 2010), który w mniejszym stopniu zajmuje się terminologią, głównie zaś analizuje cechy swoiste dyskursu medycznego, językowe wykładniki argumentacji, logiki i spójności wywodu poświęconego etiologii i rozwojowi jednostek chorobowych.

Wśród prac dotyczących poprawności słownictwa medycznego na uwagę zasługuje artykuł Zenona Klemensiewicza podejmujący kwestie związane z przyswajaniem wyrazów zapożyczonych do rodzimego języka. Autor zwraca szczególną uwagę na trudności wynikające $z$ polszczenia obcej terminologii i nomenklatury medycznej (Klemensiewicz 1963: 757-760).

Innym obszarem badań w terminologii medycznej są gwarowe nazwy chorób. O fenomenie ludowego lecznictwa jako komponentu ludowej kultury duchownej pisano też niejednokrotnie. O wybranych nazwach chorób, które funkcjonują na gruncie gwarowym, pisała Monika Buława (2016a, 2016b, 2019), wyróżniając nazwy odwołujące się do objawów choroby i nazwy kulturowe wskazujące na sposób postrzegania choroby i zawierające jej wartościowanie. Ta sama autorka analizowała przeklęcia gwarowe pod kątem występujących w ich obrębie nazw chorób epidemicznych. Na temat medycyny niekonwencjonalnej, nazw i symptomów schorzeń oraz zachowań językowych towarzyszących leczeniu powstało sporo studiów wyrastających na gruncie etnolingwistyki, by wymienić tylko prace Wandy Budziszewskiej (1975, 1989), Karoliny Bielenin (2003), Beaty Walęciuk-Dejneki (2005) czy Marzeny Marczewskiej (2010, 2012a, 2012b).

Socjolektalny charakter słownictwa medycznego podejmował w swoim studium Jerzy Obara (2003), koncentrując się na mechanizmach tworzenia nowych jednostek leksykalnych, nadawania istniejącym już wyrazom nowych znaczeń oraz inkrustowania tego socjolektu jednostkami obcojęzycznymi.

Jak wynika z powyższego przeglądu, obecnie brak odrębnego opracowania poświęconego szczegółowej analizie nazewnictwa związanego z terminologią logopedyczną, aparatem orofacjalnym czy patologią mowy.

Spośród licznych studiów poświęconych chorobom kanału ustno-nosowego (Wnęk 2015) i ich leczeniu zwraca uwagę odosobniony szkic uwzględniający staropolskie nazwy schorzeń laryngologicznych (rodzime i zapożyczone) z XV i XVI w. związanych z chorobami gardła, uszu, nosa i krtani (Steczko, Steczko, Składzień 2003). Z kolei przyczynkiem do dalszych badań polskiej terminologii logopedycznej 
w ujęciu lingwistycznym jest wieloautorska monografia pod redakcją Jana Ożdżyńskiego (1994b), o której była mowa już wcześniej. Złożyły się na nią teksty referatów wygłoszonych na konferencji naukowej w Krakowie w 1992 r. W kontekście opublikowanych przez Józefa Surowańca słowników (1992, 1993a, 1993b) uczestnicy krakowskiego sympozjum podjęli wstępną refleksję nad kwestią systematyzowania pojęć i terminów, którymi posługuje się logopedia. W zgodnej opinii językoznawców, pedagogów, psychologów i lekarzy foniatrów prace nad porządkowaniem i ujednolicaniem polskiej terminologii logopedycznej rysują się jako działania ważne oraz ambitne z uwagi na znaczną niejednorodność zasobu terminologicznego rozpatrywanej dziedziny.

Postulaty badawcze sformułowane ponad ćwierć wieku temu nie zostały jednak dotychczas podjęte w sposób, jakiego oczekuje od lat środowisko logopedów, zarówno teoretyków, w których rozważaniach dominuje refleksja metanaukowa, jak i praktyków podejmujących na co dzień działania terapeutyczne.

\section{Literatura}

AjDukiewicz K., 1960, Naukowa perspektywa świata, [w:] idem, Jęzk i poznanie, t. 1: Wybór pism z lat 1920-1939, Warszawa, s. 215-221.

ASA: American Psychiatric Association, Diagnostic and Statistical Manual of Mental Disorders. Fifth Edition, Washington - London 2013.

Bielenin K., 2003, Rytuał zamawiania chorób jako akt mowy, „Poradnik Językowy” nr 7, S. $36-53$.

BobrowsKi I., 1993, Językoznawstwo racjonalne. Z zagadnień teorii językoznawczej i metodologii opisów gramatycznych, Kraków.

Budziszewska W., 1975, Stowiańskie nazwy chorób pochodne od „gostb”, „Poradnik Językowy" nr 4, s. 200-202.

BudziszewsKa W., 1989, O niektórych nazwach chorób i związanych $z$ nimi demonów w językach słowiańskich, [w:] H. Popowska-Taborska (red.), Paralele w rozwoju słownictwa jezzyków stowiańskich, Wrocław, s. 153-160.

BUŁAWA M., 2016a, Kulturowe uwarunkowania gwarowych nazw chorób, „Polonica” XXXVI, s. 259-274, [on-line:] https://doi.org/10.17651/POLON.36.18.

BuŁaWA M., 2016b, Nazwy chorób epidemicznych w przeklęciach gwarowych, „LingVaria” nr 2 (22), s. 249-264, [on-line:] http://dx.doi.org/10.12797/LV.11.2016.22.16.

BuŁaWA M., 2019, Nazwy chorób w gwarach polskich, Kraków.

Doмвrowsкi A., 2018, Terminologia medyczna w poradnikach zdrowia dotyczacych chorób krwi a zrozumiałość tekstu, [w:] A. Dombrowski, W. Żarski (red.), Dyskurs (para)medyczny. Gatunki - funkcje - przeobrażenia, Wrocław - Kraków, s. 39-55.

Doroszewski J., 1999, Polski język medyczny, [w:] W. Pisarek (red.), Polszczyzna 20oo. Orędzie o stanie języka polskiego na przełomie tysiącleci, Kraków, s. 33-49.

Doroszewsкi J., 2010, Język nauki i praktyki medycznej, [w:] M. Milewska-Stawiany, E. Rogowska-Cybulska (red.), Polskie jezzki. O jezykach zawodowych i środowiskowych, Gdańsk, s. 299-319. 
Falimirz S., 1534, O ziołach i mocy ich, Kraków.

FrIEdelównA T., 1991, „Ochrapienie, niechęć jadła i trzęsienia serca”, czyli na co chorowali torunianie w XVII wieku, „Rocznik Toruński” XX, s. 281-293.

Friedelówna T., 1992, Polskie terminy farmaceutyczne $w$ podręczniku „Onomasticum trilingue latino-germanico-polonicum”, [w:] H. Wiśniewska, C. Kosyl (red.), Odmiany polszczyzny XVII wieku, Lublin, s. 115-122.

Friedelówna T., 1994, Terminologia medyczna $w$ toruńskim farmaceutycznym „Onomasticum” P. Guldeniusza i w „Przymiocie” W. Oczki, „Polszczyzna Regionalna Pomorza. Zbiór studiów" 6, s. 29-35.

Gajda S., 1990, Wprowadzenie do teorii terminu, Opole.

Gonigroszek D., 2017, Polska terminologia medyczna - spojrzenie diachroniczne, [w:] R. Maćkowiak, E. Wojtczak (red.), Bogactwo językowe i kulturowe Europy w oczach Polaków i cudzoziemców, t. 4. Łódź, s. 185-192.

Grabias S., 1991, Logopedia - jej przedmiot i stopień zaawansowania refleksji metanaukowej, [w:] H. Borowiec i in. (red.), Przedmiot logopedii, „Komunikacja Językowa i Jej Zaburzenia”, t. 1, Lublin, s. 26-49.

Grabias S., 2012, O ostrość refleksji naukowej. Przedmiot logopedii i procedury logopedycznego postępowania, [w:] S. Milewski, K. Kaczorowska-Bray (red.), Logopedia. Wybrane aspekty historii, teorii i praktyki, Gdańsk, s. 56-69.

Grabias S., 2019, Język w zachowaniach społecznych. Podstawy socjolingwistyki i logopedii, Lublin.

GruCzA F., 1983, Zagadnienia metalingwistyki. Lingwistyka - jej przedmiot, lingwistyka stosowana, Warszawa.

Hajduк Z., 2012, Ogólna metodologia nauk, Lublin.

HAMERliŃsKa A., 2017, Metodyka logopedyczna w przypadku osób po laryngektomii całkowitej, „Annales Universitatis Paedagogicae Cracoviensis. Studia Logopaedica” 6, s. 89-10o.

IngARden R., 1966, Czego nie wiemy o wartościach? [w:] idem, Przeżycie, dzieło, wartość, Kraków, s. 83-127.

JANIUK J., 2005, Terminologia i problematyka medyczna we wczesnych (1931-1939) utworach Michała Choromańskiego, „Medycyna Nowożytna. Studia nad Kulturą Medyczną” XII, nr 1-2, s. 19-51.

Jankowiak L.A., 2011a, Polskie słownictwo medyczne $w$ drugiej połowie XIX wieku oraz na przełomie XIX i XX wieku, „Studia Językoznawcze. Synchroniczne i diachroniczne aspekty badań polszczyzny" X, s. 97-109.

JANKOWIAK L.A., 2011b, Synonimia w polskiej terminologii medycznej przełomu XIX i XX wieku. Rekonesans, „Studia z Filologii Polskiej i Słowiańskiej” XLVI, s. 233-262, [on-line:] https://doi.org/10.11649/sfps.2011.002.

Kaczmarek L., 1991, O polskiej logopedii, [w:] H. Borowiec i in. (red.), Przedmiot logopedii, „Komunikacja Językowa i Jej Zaburzenia”, t. 1, Lublin, s. 5-25.

Kamiński S., 1992, Nauka i metoda. Pojęcie nauki i klasyfikacja nauk, do dr. przygot. A. Bronk, wyd. 4 popr., Lublin.

KĘDelska E., 1978, Polska terminologia medyczna w słownikach Bartłomieja z Bydgoszczy, „Studia z Filologii Polskiej i Słowiańskiej” XVII, s. 95-104.

KLEMENSIEwicz Z., 1963, Językoznawca wobec problematyki słownictwa lekarskiego, „Neurologia, Neurochirurgia i Psychiatria Polska” XIII, nr 6, s. 757-76o.

Knapski G., 1621, Thesaurus Polono-Latino-Graecus seu Promptuarium Linguae Latinae et Graecae Polonorum usui accomodatum..., Cracoviae. 
KozoŁub A., 2003, Anatomia i fizjologia narządów mowy, głosu i słuchu, [w:] T. Gałkowski, G. Jastrzębowska (red.), Logopedia. Pytania i odpowiedzi. Podręcznik akademicki, t. 1, Opole, s. 127-143.

Kuczkowski J., Cieszyńska J., 2017, Dzieje polskiej foniatrii, [w:] S. Milewski, K. Kaczorowska-Bray, B. Kamińska (red.), Studia logopedyczno-lingwistyczne. Ksiega jubileuszowa z okazji 7o-lecia urodzin Profesora Edwarda Łuczyńskiego, Gdańsk, s. 63-81.

Linde S.B., 1807-1814, Słownik języka polskiego, t. 1-6, Warszawa.

Logopedia: S. Grabias, J. Panasiuk, T. Woźniak (red.), Logopedia. Standardy postępowania logopedycznego, Lublin 2015.

ŁAWNiCKA-BorońsKa M., KuBACKA K., 2016, Język polski medyczny w wybranych materiałach dydaktycznych ostatniego ćwierćwiecza, „Acta Universitatis Lodziensis. Kształcenie Polonistyczne Cudzoziemców” 23, s. 215-235, [on-line:] https://doi.org/10.18778/ 0860-6587.23.17.

MarCzewska M., 2010, Strategie pragmatyczne stosowane w zamówieniach ludowych, [w:] H. Bartwicka (red.), Język, tekst, kultura, Bydgoszcz, s. 115-128.

MarCzewska M., 2012a, Ja cię zamawiam, ja cię wypędzam... Choroba. Studium językowo-kulturowe, Kielce.

Marczewska M., 2012b, Performatywność polskich zamówień znachorskich, [w:] A. Burzyńska-Kamieniecka (red.), Akty i gatunki mowy w perspektywie kulturowej, „Język a Kultura", t. 23, Wrocław, s. 367-381.

MasŁowski J., 1977, Polskie słownictwo lekarskie, Wrocław.

MąCZyŃski J., 1564, Lexicon Latino-Polonicum ex Optimis Latinae linguae scriptoribus concinnatum, Regiomonti Borussiae.

Metodologia: S. Milewski, K. Kaczorowska-Bray (red.), Metodologia badań logopedycznych z perspektywy teorii i praktyki, Gdańsk 2015.

Michalik M., 2013, Teoria logopedii jako interakcja. Między interakcjonizmem symbolicznym a lingwistyka mentalną, [w:] M. Michalik, A. Siudak, H. Pawłowska-Jaroń (red.), Interakcyjne uwarunkowania rozwoju i zaburzeń mowy, „Nowa Logopedia”, t. 4, Kraków, s. 13-31.

Michalik M., 2015, Transdyscyplinarność logopedii - między metodologiczna koniecznościa a teoretyczna utopia, [w:] S. Milewski, K. Kaczorowska-Bray (red.), Metodologia badań logopedycznych z perspektywy teorii i praktyki, Gdańsk, s. 32-46.

Michaliк M., 2018, Lingwistyczno-logopedyczne podstawy komunikacji alternatywnej i wspomagającej. Ujęcie metodologiczne, Kraków.

Migdat J., 2002, O nazywaniu człowieczych chorób - uwagi o słownictwie Glaberowych „Gadek", [w:] M. Białoskórska, L. Mariak (red.), Synchroniczne i diachroniczne aspekty badań polszczyzny, t. 8: Materiały X Kolokwium Językoznawczego, Pobierowo, 18-20 września 2000 r., Szczecin, s. 147-157.

MusioŁek-Choiński K., 1986, Polskie nazwy chorób. Studium z terminologii medycznej, Wrocław.

Nowy Leksy kon: K. Czarnecki (red.), Nowy leksykon metodologiczny, Sosnowiec 2009.

ОваRа J., 2003, Współczesne socjolektalne słownictwo medyczne, „Kształcenie Językowe” 4, S. $147-185$.

Oвręвоwsкi A., 2014, Biologiczne podstawy mowy, [w:] S. Milewski, J. Kuczkowski, K. Kaczorowska-Bray (red.), Biomedyczne podstawy logopedii, Gdańsk, s. 23-35. 
Окоnіоша J., 2018, „Szlachetne zdrowie...” - dyskurs medyczny w staropolszczyźnie, [w:] A. Dombowski, W. Żarski (red.), Dyskurs (para)medyczny. Gatunki-funkcje-przeobrażenia, Wrocław - Kraków, s. 141-153.

OżDżyński J., 1994a, Słowo wstępne, [w:] idem (red.), Polska terminologia logopedyczna, Kraków, s. 7-9.

OżDŻYŃsKi J. (red.), 1994b, Polska terminologia logopedyczna, Kraków.

Popper K.R., 1992, Wiedza obiektywna. Ewolucyjna teoria epistemologiczna, tłum. A. Chmielewski, Warszawa.

PUKALSKA B., 2013, „Złapać bakcyla”, czyli o ewolucji znaczeń niektórych wyrazów z leksyki medycznej i potocznej, „Linguarum Silva”, t. 2, s. 71-90.

Puzıo A., ZıóŁKowska K., 1998, Wybrane zagadnienia z metodyki pracy naukowej. Skrypt dla studentów i doktorantów, Katowice.

Ross J., 1965, Z dziejów polskiego słownictwa lekarskiego, „Język Polski” XLV, s. 223-234.

SienNiK M., 1568, Herbarz to jest zioł tutecznych, postronnych i zamorskich opisanie..., Kraków.

SPICZYŃsKi H., 1542, O ziołach tutecznych i zamorskich i o mocy ich..., Kraków.

SPólniK A., 1988, Nazwy polskich roślin leczniczych w źródłach od XVI do XVIII wieku, [w:] W. Boryś (red.), Studia konfrontatywne i historia, „Studia Językoznawcze. Streszczenia prac doktorskich", t. 12, Wrocław, s. 177-228.

SPólNiK A., 1990, Nazwy polskich roślin do XVIII wieku, Wrocław.

Steczko A., Steczko I., SkŁadzień J., 2003, Katarrus, chrapota, ślinogorz, czyli o nazwach i leczeniu schorzeń laryngologicznych na podstawie zabytków języka polskiego z XV i XVI wieku, „Otolaryngologia Polska” LVII, nr 2, s. 295-30o.

Surowaniec J., 1992, Słownik terminów logopedycznych, Kraków.

Surowaniec J., 1993a, Podręczny słownik logopedyczny, Kraków.

Surowaniec J., 1993b, Słownik słów kluczowych w logopedii, Kraków.

Surowaniec J., 1999, Logopedyczny słownik terminologii diagnostycznej, Kraków.

Syreniusz S., 1613, Zielnik herbarzem z języka łacińskiego zowią..., Kraków.

Trotz M.A., 1764, Nowy dykcjonarz, to jest Mownik polsko-niemiecko-francuski..., Lipsk.

Umińska-Tytoń, E., 1989, Potoczne nazwy chorób i dolegliwości w księgach parafialnych Mileszek $z$ XVIII wieku, cz. 1, „Rozprawy Komisji Językowej Łódzkiego Towarzystwa Naukowego" XXXV, s. 205-218.

Umińska-Tytoń, E., 1990, Potoczne określenia chorób i dolegliwości w księgach parafialnych Mileszek z XVIII wieku, cz. 2, „Rozprawy Komisji Językowej Łódzkiego Towarzystwa Naukowego" XXXVI, s. 199-205.

Wajda-AdAмczy коwa L., 1989, Nazwy roślin leczniczych, [w:] B. Kuźnicka (red.), Historia leków naturalnych, t. II: Natura i kultura - współzależności w dziejach lekoznawstwa, Warszawa, s. 69-82.

WalęCIUK-DejneKa B., 2005, Magiczne sposoby leczenia w tradycyjnej medycynie ludowej. Symbolika słów i gestów w aktach zażegnywania, zaklinania i zamawiania choroby, [w:] E. Łoch, G. Wallner (red.), Między literatura i medycyną. Literackie i pozaliterackie działania środowisk medycznych a problemy egzystencjalne człowieka XIX $i$ XX wieku, Lublin, s. 67-76.

Wiśniewska H., 1991, Terminologia medyczna $w$ rozprawie „De ossibus humanis tractatus tres” Jana Ursinusa, „Prace Filologiczne” XXXVI, s. 369-378. 
WNĘK J., 2015, Krytyka naukowa polskich książek medycznych na przełomie XIX i XX wieku, "Archiwum Historii i Filozofii Medycyny” LXXVIII, s. 75-88.

Wysocka F., 1980, Polska terminologia lekarska do roku 1838, t. I: Anatomia - proste prymarne nazwy nie motywowane, Wrocław.

Wysocka F., 1994, Polska terminologia lekarska do roku 1838, t. II: Anatomia, jednowyrazowe nazwy motywowane, Kraków.

WysockA F., 1995, Kształtowanie się polskiej terminologii anatomicznej do początków XIX w., „Medycyna Nowożytna. Studia nad Historią Medycyny” II, nr 2, s. 71-82.

WysockA F., 1999, Zarys historii literatury medycznej i piśmiennictwa medycznego do początków XIX wieku, Piotrków Trybunalski.

Wysocka F., 2007, Polska terminologia lekarska do roku 1838, t. III: Anatomia, nazwy dwuwyrazowe, Kraków.

Wysocka F., 2013, Polska terminologia lekarska do roku 1838, t. IV: Anatomia, nazwy wielowyrazowe, Kraków.

ŻyCIŃsKi J., 1983, Język i metoda, Kraków.

\section{At the Sources of Polish Logopedic Terminology. Towards Anagnostic Research Summary}

The paper is a preliminary presentation of the concept of a research project Diachronic aspects of Polish logopedic terminology, carried out by members of the Department of Polish Language of the Pedagogical University in Cracow. The multiauthored study briefly characterizes the beginnings of speech therapy as an independent scientific discipline, and the directions of its development in the past 50 years. It draws attention to the deficiencies and inconsistencies in the usage and understanding of specialist terms in contemporary logopedics, while setting as the primary goal of the enterprise an attempt to standardize Polish terminology related to speech disorders. The basis for this should be the etymology of the terms in question, as well as excerpts from medical and anatomical lexicons and source materials which employ the vocabulary that became the foundation of the logopedic jargon. 